\title{
Is There a Difference in Credit Constraints Between Private and Listed Companies in Brazil? Empirical Evidence by The Cash Flow Sensitivity Approach
}

\author{
Alan Nader Ackel Ghani \\ PhD Student, Business Administration Department, School of Economics, Administration and Accounting, University of São Paulo \\ e-mail: alanghani@usp.br \\ Roy Martelanc \\ Professor, Business Administration Department, School of Economics, Administration and Accounting, University of São Paulo \\ e-mail: rmartela@usp.br \\ Eduardo Kazuo Kayo \\ Professor, Business Administration Department, School of Economics, Administration and Accounting; University of São Paulo \\ e-mail: kayo@usp.br \\ Received on 4.28.2014-Desk acceptance 5.2.2014 - $2^{\text {nd }}$ version accepted 9.2.2014
}

\begin{abstract}
This article analyzes the credit constraints, using the cash flow sensitivity approach, of private and listed companies between 2007 and 2010. According to this approach, the econometric results show that the credit constraints are the same for either private or listed companies. This paper seeks to contribute to the literature because the study of credit constraints of private companies based on cash flow sensitivity in Brazil has been rare.
\end{abstract}

Keywords: credit constraints, cash flow sensitivity, private companies 


\section{INTRODUCTION}

According to Fazzari, Glenn and Petersen (1988), information asymmetry causes capital constraints by raising the costs of external financing ${ }^{1}$ (debt or issuance of shares), because shareholders and creditors will charge premiums for taking the risk of financing struggling companies, masked by the lack of information transparency between managers and investors. The less transparent the information of a company is, the more difficult (high interest rates or legal restrictions) it will be to obtain credit or to issue shares to finance its operating activities. In turn, the greater the information asymmetry is, the more the company will use internal funds to finance its investments because these companies have higher constraints regarding external sources of capital.

To measure the degree of corporate capital constraints, Fazzari et al. (1988) proposed an econometric model in which investment was a function of Tobin's $\mathrm{Q}$ (a variable that captures future investment opportunities) and operating cash flow. According to this approach, if the company did not have capital constraints, investment would not be significantly correlated with cash flow because the company would use credit or the issuance of shares to finance itself, and all cash surplus would be distributed in the form of dividends. Conversely, if the company had external financing constraints generated by information asymmetry between managers and investors, the cash flow would have a significant and positive correlation with investment. This approach to measuring the degree of capital constraints of companies is known as cash flow sensitivity (investment sensitivity to cash flow fluctuations). In summary, the higher the information asymmetry of a company is, the greater the external financing constraints are, reflected in increased investment-cash flow sensitivity.

In principle, private companies, due to having more information asymmetry in light of the lower requirements regarding information transparency to the market, should have greater credit constraints caused by a grea- ter correlation between cash flow and investment. Given this hypothesis, the main objective of this study is to use the cash flow sensitivity approach to determine whether private companies indeed have higher credit constraints, compared to listed companies. Although there have been other studies of the cash flow sensitivity of Brazilian companies, including those by Terra (2003) and Aldrighi and Bisinha (2010), the application of this approach for private companies is unprecedented in Brazil.

A comparison of investment-cash flow sensitivity between private and listed companies was conducted through econometric analysis in a dynamic panel, using a sample obtained from the Institute for Accounting, Actuarial and Financial Research Foundation (Fundação Instituto de Pesquisas Contábeis, Atuariais e Financeiras - Fipecafi), consisting of 164 listed companies and 688 private companies in the period from 2007 to 2010.

The results showed no difference in credit constraints for listed or private companies because the difference in investment-cash flow sensitivity was not statistically significant between them, according to the cash flow sensitivity approach.

At first, an interaction term was used to differentiate listed companies from private ones. To analyze robustness, estimates were also obtained using separate regressions (only private companies) and other methods: OLS (ordinary least squares) or OLS with lagged dependent variables, in addition to first-difference GMM (generalized method of moments; Wooldridge, 2002). In all of the cases, the results were very similar.

In addition to this introduction, the present study is organized as follows: section 2 presents a literature review on the topic, and section 3 presents the econometric methodology. Section 4 describes the sample data, whereas the econometric results are shown and analyzed in section 5 , and finally, in section 6 , the final conclusions are presented.

\section{LITERATURE REVIEW}

The measurement of capital constraints by the econometric cash flow sensitivity approach, controlled by other variables (usually Tobin's Q), is a very current topic and has been widely discussed in corporate finance.

This line of research began with an article by Fazzari et al. (1988). In this study, the authors partitioned the sample according to the distributions of dividends, based on the following premise: companies that pay fewer dividends are considered more constrained because they would have to retain cash to fund their investments. In addition to confirming this hypothesis, the article encouraged the application of the cash flow sensitivity approach in several subsequent studies that attempted to capture the capital constraints for different companies from the perspective of different variables (size, credit rating, financial market proximity, asset tangibility).

Hoshi (1991), for example, found that companies with close relationships to bankers (belonging to a keiretsu - a Japanese industrial group) have fewer capital constraints. Furthermore, Gilchrist and Himmelberg (1995) showed that companies that undergo credit rating evaluations (commercial paper issuers) have lower credit constraints, while Carpenter and Petersen (2002) showed that new firms linked to the technology sector had more external financing constraints. 
Moreover, Almeida and Campelo (2007) showed the importance of collateral (tangibility) in reducing credit constraints. In the following year, Ratti, Lee and Seol (2008) showed that banking concentrations reduced the credit constraints of companies.

In Brazil, Aldrighi and Bisinha (2010) showed that large companies had higher investment-cash flow sensitivity, contradicting the results of Terra (2003), who showed that large companies and multinationals had lower credit constraints. However, the author showed that, with the exception of these two groups, Brazilian companies exhibited, on average, capital constraints from 1986 to 1997. To reach this conclusion, Terra adopted two different approaches: the classical approach, in which Tobin's $\mathrm{Q}$ appears as a control variable in the cash flow sensitivity model; and another approach, in which current and lagged income replaces Tobin's Q to capture investment opportunities. Both models reached the same results.

Brown and Petersen (2009) drew attention to the increase in cash flow sensitivity coefficients over the years. To the authors, this decline indicated lower capital constraints due to the development of the stock market in the United States (creation of Nasdaq - National Association of Securities Dealers Automated Quotations, in the 1970s) and a greater weight of investments in intangible assets not captured in previous studies.

However, there have been studies criticizing this approach. Kaplan and Zingales (1997), Cleary (1999) and Kadapakkam, Kumar and Riddick (1998) questioned the cash flow sensitivity methodology. In broad terms, the studies showed that companies with better financial health (more cash availability, lower levels of debt) are those with the highest investment-cash flow sensitivity.

In Moyen's view (2004), differences in the interpretation of the investment-cash flow sensitivity coefficient result from the type of sample partitioning. If this relationship is tested for samples rated according to information asymmetry criteria (size, retention of dividends, capital control, among others), cash flow sensitivity will capture capital constraints, as initially proposed by Fazzari et al. (1988). However, if companies are grouped according to factors related to the availability of internal funds, the investment-cash flow sensitivity coefficient will have the opposite relationship, i.e., the better that the financial health of a company is, the greater the investment-cash flow sensitivity is.

Cleary (2007) confirmed the interpretation of Moyen (2004), using a theoretical model (U curve) that was empirically tested. In his study, the results showed that support the works by Fazzari et al. (1988) and by Kaplan and Zingales (1997). Guaraglia (2008) also confirmed the U curve. To reach this conclusion, the author analyzed private companies in the UK. If companies are rated according to information asymmetry criteria, the investment-cash flow sensitivity increases with increasing constraints. However, if companies are rated according to the availability of internal funds or with financial indices, the greater the capital constraints are, the lower the investment-cash flow sensitivity is.

The notion behind the $U$ curve is that companies in bad financial conditions would use more credit to invest and ensure their survival (negative relationship) when facing cash flow reductions. Conversely, companies in good financial condition, as their cash flow increased, would use more internal funds to invest not to suffer a capital cost increase (cost effect). According to the author, the central point for the divergence of results is to understand whether, in fact, credit constraints are conditioned by information asymmetry or by issues related to the financial performances of companies.

Another issue raised in the literature (Alti, 2003) is that the use of Tobin's average $\mathrm{Q}$ in the regression as a non-observable proxy of Tobin's marginal $Q$ can generate biased results in the interpretation of cash flow sensitivity.

Despite the differences in the interpretation of cash flow sensitivity, the investment-cash flow sensitivity continues to be investigated fairly and to be used as a credit constraint measurement.

\section{ECONOMETRIC METHODOLOGY}

Because the present study investigates the investment-cash flow sensitivity - including for private companies - the use of Tobin's $\mathrm{Q}$ as a control variable will not be possible, because the market value of private companies is not available. In this case, the sales accelerator model used by Terra (2003) is adopted:

$$
\left(I_{i t} / K_{i t-1}\right)=\alpha_{i}+\beta_{1}\left(I n c_{i t} / K_{i t-1}\right)+\beta_{2}\left(\operatorname{Inc}_{i t-1} / K_{i t-1}\right)+\beta_{3}\left(C F_{i t} / K_{i t-1}\right)+\beta_{4} D_{i t} \cdot\left(C F_{i t} / K_{i t-1}\right)+u_{i t}
$$

The sales accelerator model assumes that the investment made in a given year is a function of current income and income from the previous year. Income increases would signal greater investment opportunities due to the need for company growth. Thus, the income variable would replace Tobin's $Q$ as an indicator variable of investment opportunities.
In the absence of capital constraints, which assume there is no difference in costs between internal financing and external financing to the company, the investment should be financed only with debt equity or the issuance of shares, and all of the cash flow generated should be distributed in the form of dividends. Thus, if cash flow is related to investment, it is an indication of capital constraints, to 
the extent that the company uses internal funds to finance itself (Fazzari et al., 1998). Thus, the cash flow variable ( $C F_{i t}$ ) is included in the sales accelerator model described above to capture capital constraint. As in Aldrighi and Bisinha (2010), the EBITDA variable is used as a proxy for cash flow $\left(C F_{i t}\right)$, which is obtained from the sum of operating income plus depreciation. Variable $I_{i t}$ is the investment in fixed assets (Capex - capital expenditure) held by a particular company during year $t$. The investment is calculated by the difference between the fixed assets from one year to another. Variables Inc ${ }_{i t}$ and Inc ${ }_{t-1}$ represent the company's income in year $t$ and the previous year $t-1$, respectively. The $\mathrm{D}_{\mathrm{it}} \mathrm{CF}_{\mathrm{it}}$ variable represents the interaction term to capture the difference in the cash flow coefficient between listed and private companies (private $\mathrm{D}=0$, and listed company $\mathrm{D}=1)$. All of the variables were divided by fixed assets from the previous year $\left(K_{i t-1}\right)$ to avoid size distortions.

The model hypothesis is the same as that discussed in the previous sections. If the $B_{3}$ coefficient of the cash flow has a significant relationship with investment, that is an indication of capital constraint; otherwise, there is no credit constraint. In turn, the interaction dummy measures the existence of differences in credit constraints between private and listed companies. It is worth remembering that the cash flow coefficient of listed companies is the linear combination (sum) of the cash flow coefficient and interaction dummy.

The analysis is performed by the first-difference GMM technique proposed by Arellano and Bond (1991). Widely used in this literature, the use of the lagged dependent variable (dynamic panel) is justified by the correlation between current investment and past investment. It is reasonable to assume that unobservable, idiosyncratic fixed factors of the company affect investment decisions and are related to the explanatory variables (income and cash flow). In this case, the fixed effect is removed by the first difference. However, the presence of the lagged variable using the first difference generates endogeneity that is corrected with instrumental variables that are the higher lags of the explanatory variables in the model. The use of these instruments must be validated by the Sargan test (Wooldridge, 2002), and the errors should not be auto-correlated. The statistics of these tests are presented in section 5 (Result Analysis).

It is worth noting that these instruments only solve the problem generated by the actual removal of fixed effects from the dynamic panel. It is reasonable to question that there might be a simultaneity bias between cash flow and investment. This type of endogeneity, in this line of research, has been little explored in the literature. In fact, the investment made in one year can generate cash flow in the same year. However, this effect is small in almost all cases because the investment is relatively small relative to existing assets, and such investment generates cash flow for a limited number of months during the year. Therefore, it is expected that the incremental cash flow generated by investment during the year is small, compared to the existing cash flow.

Although the focus of interest is the first-difference GMM, the results are reported by POLS and dynamic POLS (with the lagged dependent variable), although in these cases, stronger assumptions are required regarding the relationship between the error and the explanatory variables. The presentation of results using other techniques requires more robustness of the study in that it assesses the stability of results when using different techniques.

Finally, questions could be raised regarding the issues of multicollinearity and autocorrelation between the variables. Regarding the issue of (imperfect) multicollinearity between income and cash flow, it is noted that such problems do not lead to estimation bias, leading only to an increase in the standard error of the estimator. In contrast, autocorrelation could be a problem in the case of large panels. However, in small panels, as in the case of the present study, this issue becomes negligible (Wooldridge, 2002).

\section{DATA DESCRIPTION}

Data for the study were provided by Fipecafi². The sample consists of annual balance sheet data $(2007,2008$, 2009,2010 ) of the top 1,000 companies (private and listed companies) rated by Fipecafi according to net income. The "Top 1,000" correspond to the 1,000 highest net income values for each year. Because the data from 1,000 companies were provided for the four years mentioned, the initial sample included 4,000 observations. However, not all of the companies were included in the sample for each year. There have been companies that have reached a certain level of income in one year but not in a different year. In addition, some companies have not reported the data required for the study. Thus, the final sample consisted of 852 companies and 2,651 observations in an unbalanced panel. Of these companies, $81 \%$ are private, and $19 \%$ are listed (Table 1).

\begin{tabular}{|c|c|c|}
\hline Capital Control & $n^{\circ}$ & $\%$ \\
\hline Listed companies & 164 & $19 \%$ \\
\hline Private companies & 688 & $81 \%$ \\
\hline Total & 852 & $100 \%$ \\
\hline
\end{tabular}

Source: Fipecafi

Table 2 shows the sample composition by sector. It is worth remembering that this type of study excludes financial companies because there would not be a clear division among financing, investment and operating results. According to table 2, the stock market in Brazil is well diversified, with emphases on the energy and services sectors. Of this total, $67 \%$ of the sample companies are Brazilian and private, $8 \%$ are Brazilian state-owned companies, and the remainder are foreign multinationals. 


\begin{tabular}{|c|c|c|}
\hline Sector & $\mathrm{n}^{\circ}$ & $\%$ \\
\hline Wholesale & 57 & $7 \%$ \\
\hline Automotive & 29 & $3 \%$ \\
\hline Capital Goods & 21 & $2 \%$ \\
\hline Consumer Goods & 71 & $8 \%$ \\
\hline Communications & 9 & $1 \%$ \\
\hline Miscellaneous & 12 & $1 \%$ \\
\hline Electronics & 29 & $3 \%$ \\
\hline Energy & 111 & $13 \%$ \\
\hline Pharmaceutical & 16 & $2 \%$ \\
\hline Construction Industry & 52 & $6 \%$ \\
\hline Computer Industry & 20 & $2 \%$ \\
\hline Mining & 20 & $2 \%$ \\
\hline Paper and Pulp & 21 & $2 \%$ \\
\hline Agriculture & 39 & $5 \%$ \\
\hline Chemical and Petrochemical & 69 & $8 \%$ \\
\hline Services & 87 & $10 \%$ \\
\hline Steelworks & 56 & $7 \%$ \\
\hline Telecommunications & 19 & $2 \%$ \\
\hline Textiles & 23 & $3 \%$ \\
\hline Transportation & 34 & $4 \%$ \\
\hline Retail & 57 & $7 \%$ \\
\hline Total & 852 & $100 \%$ \\
\hline
\end{tabular}

Source: Fipecafi

Table 3 shows the mean and median values of the study variables. The discrepancy between the mean and the median in the sample is explained by the existence of observations with high values in the sample. The results show that investment has remained almost stable over the years, with slight increases in 2007 and 2010. In those same years, cash flow and income had the highest means and medians, compared to other periods. It is worth noting that the economy exhibited growth of $6.09 \%$ in 2007 and $7.53 \%$ in 2010 (Banco Central, 2012).

\section{Table 3}

Mean and Median Variables

\begin{tabular}{|c|c|c|c|c|c|c|c|c|}
\hline \multirow[t]{2}{*}{ Variables } & \multicolumn{2}{|c|}{2007} & \multicolumn{2}{|c|}{2008} & \multicolumn{2}{|c|}{2009} & \multicolumn{2}{|c|}{2010} \\
\hline & Mean & Median & Mean & Median & Mean & Median & Mean & Median \\
\hline Income/Kt-1 & 44.39 & 4.91 & 34.28 & 4.76 & 22.74 & 4.30 & 59.72 & 5.50 \\
\hline Cash Flow/Kt-1 & 1.44 & 0.45 & 1.97 & 0.49 & 1.39 & 0.37 & 7.80 & 0.46 \\
\hline Investment/Kt-1 & 4.59 & 0.04 & 3.56 & 0.04 & 3.77 & 0.04 & 4.71 & 0.07 \\
\hline
\end{tabular}

Source: Prepared by the author with Fipecafi data

\section{RESULTS AND ANALYSIS}

Table 4 presents the results using the interaction dummy to capture the differences in the cash flow coefficient of private and listed companies. It is interesting to note that despite the different methods used, the results point in the same direction, indicating no difference in the investment-cash flow sensitivity between the listed companies and private companies. 


\begin{tabular}{|c|c|c|c|}
\hline \multicolumn{4}{|c|}{ Dependent Variable: Investment } \\
\hline Independent Variables & First-difference GMM & OLS & Dynamic OLS \\
\hline \multirow[t]{2}{*}{$(\mathrm{CF} / \mathrm{K})_{\mathrm{i}, \mathrm{t}}$} & -0.00208 & -0.0440 & -0.0463 \\
\hline & $(0.0673)$ & $(0.0465)$ & $(0.0301)$ \\
\hline$(\operatorname{lnc} / K)_{i, t}$ & $(0.00947)$ & $(0.00633)$ & $(0.00440)$ \\
\hline \multirow[t]{2}{*}{$(\operatorname{lnc} / \mathrm{K})_{\mathrm{i}, \mathrm{t}-1}$} & -0.0142 & 0.00763 & -0.00321 \\
\hline & $(0.0107)$ & $(0.00500)$ & $(0.00277)$ \\
\hline \multirow[t]{2}{*}{$(\mathrm{DCF} / \mathrm{K})_{\mathrm{i}, \mathrm{t}}$} & -0.0812 & $0.152^{*}$ & 0.103 \\
\hline & $(0.0549)$ & $(0.0917)$ & $(0.0815)$ \\
\hline Constant & & $0.710^{* * *}$ & $0.441^{* * *}$ \\
\hline No. of Observations & 624 & 1.639 & 1.075 \\
\hline R squared & & 0.080 & 0.468 \\
\hline No. of Companies & 357 & & \\
\hline J test ( $p$ value) & 0.4919 & & \\
\hline Autocorrelation Test ( $p$ value) & 0.0910 & & \\
\hline
\end{tabular}

Note: Source - Fipecafi. ${ }^{* *} \mathrm{p}<0.01,{ }^{* *} \mathrm{p}<0.05,{ }^{*} \mathrm{p}<0.1$. Robust errors in brackets. Instruments validated by Sargan test (H0: instruments are valid). Lack of autocorrelation between errors in first difference (H0: lack of first-order autocorrelation). K: fixed assets in t-1. I: Investment. Inc: Income. DCF: Interaction dummy to capture differences between the coefficient of listed and private companies.

The results show that lagged investment during a period is correlated with the investment during the following year. Such a result is also intuitive because companies that invested more in the past tend to invest more in the subsequent year to maintain the same level of operating activities. It is noteworthy that the instrumentalization through the use of the lagged dependent variable in the dynamic panel was validated by the Sargan test and the error autocorrelation test, at a 5\% significance level.

In turn, the interaction dummy was significant only for $10 \%$ of the model by OLS without the lagged dependent variable. However, it is worth noting that the cash flow coefficient for listed companies is measured by the sum of the interaction dummy with the cash flow of the regression and not by the isolated value of the interaction dummy. In the three models, the cash flow coefficient of listed companies is not significant for the linear form (sum of cash flow with the interaction dummy).

In other words, the three methods indicate that there were no differences in credit constraints for listed companies, compared to private companies. This result does not confirm the hypothesis that listed companies should have lower capital constraints as a result of having less information asymmetry. A possible explanation for this finding is that private companies within the top 1,000 companies can have a high level of disclosure (information transparency) due to being very large companies with high market visibility that might consider IPOs in the near future.

Another possible explanation for the phenomenon is that Brazilian companies have low turnover, behaving in practice as private companies. To support this hypothesis, the turnover of Brazilian companies was calculated with data from the Capital IQ database and was compared with the turnover of US companies. The turnover was calcu- lated by the "annualization" of the average daily trading volume per company in the stock exchange divided by its market value. The results indicate that the turnover is much lower in Brazil than in the US. While the median Brazilian turnover is $21 \%$, the $1^{\text {st }}$ quartile is $4 \%$, and the $3^{\text {rd }}$ quartile is $55 \%$, in the US, the median turnover is $82 \%$, the $1^{\text {st }}$ quartile is $4 \%$, and the $3^{\text {rd }}$ quartile is $178 \%$. It could also be argued that the similar behavior between listed and private companies in Brazil is related to the performance of private equity funds that increase the liquidity of private companies. Nevertheless, the results are consistent with the study of Chen and Chen (2012), showing the disappearance of the investment-cash flow sensitivity in companies located in the US during the financial crisis in that country but without identifying a specific cause for the phenomenon. From the perspective of Brown and Petersen (2009), the disappearance of the investment-cash flow sensitivity is linked to investments in intangible assets not captured in balance sheets and to the development of the capital market. Both arguments could be valid in the Brazilian context. The investment data used in this study refer only to investments in fixed assets. Thus, there could be a dependency of the cash flow on investments in intangible assets not captured by a limitation of the study data. In turn, the development of the capital market might have led Brazilian companies to become less dependent on their internal cash flow to finance their expansion. Such a line of thinking is confirmed by the growing number of initial public offerings (IPOs) during the period. In 2007, 64 companies made public offerings of its shares.

Another factor that might have reduced the capital constraints was the credit incentive promoted by the Brazilian government (release of funds and reduction of the interest rate) during the US banking crisis, aiming to avoid the stag- 
nation of Brazilian companies. It is worth mentioning that, in addition to the increase in the credit volume, the basic interest rate of the economy continued on a downward trend.

To give more robustness to the results, regressions were obtained separately for the private and listed companies. The results were similar to the model with the use of the interaction dummy, evidencing no credit constraint in both cases (Tables 5 and 6).

\begin{tabular}{|c|c|c|c|}
\hline \multicolumn{4}{|c|}{ Dependent Variable: Investment } \\
\hline Independent Variables & First-difference GMM & OLS & Dynamic OLS \\
\hline \multirow{2}{*}{$(I / K)_{i, t-1}$} & $-0.449^{* * *}$ & & $1.003^{* * *}$ \\
\hline & $(0.0419)$ & & $(0.108)$ \\
\hline \multirow[t]{2}{*}{$(\mathrm{CF} / \mathrm{K})_{\mathrm{i}, \mathrm{t}}$} & -0.0708 & -1.371 & 0.00383 \\
\hline & $(0.231)$ & $(1.324)$ & $(0.557)$ \\
\hline \multirow[t]{2}{*}{$(\operatorname{lnc} / K)_{i, t}$} & 0.0292 & 0.450 & 0.189 \\
\hline & $(0.0759)$ & $(0.359)$ & $(0.162)$ \\
\hline \multirow[t]{2}{*}{$(\operatorname{lnc} / K)_{i, t-1}$} & -0.00312 & 0.170 & -0.123 \\
\hline & $(0.0600)$ & $(0.237)$ & $(0.115)$ \\
\hline \multirow[t]{2}{*}{ Constant } & & -0.361 & -0.275 \\
\hline & & $(0.706)$ & $(0.469)$ \\
\hline No. of Observations & 160 & 378 & 256 \\
\hline R squared & & 0.311 & 0.901 \\
\hline No. of Companies & 90 & & \\
\hline J test ( $p$ value) & 0.3743 & & \\
\hline Autocorrelation Test ( $p$ value) & 0.9876 & & \\
\hline
\end{tabular}

Note: Source - Fipecafi. *** $\mathrm{p}<0.01, * * \mathrm{p}<0.05, * \mathrm{p}<0.1$. Robust errors in brackets. Instruments validated by Sargan test (H0: instruments are valid). Lack of autocorrelation between errors in first difference (H0: lack of first-order autocorrelation). K: fixed assets in t-1. I: Investment. Inc: Income.

Table 6 Regression Results for the Sample with Only Private Companies

\begin{tabular}{|c|c|c|c|}
\hline \multicolumn{4}{|c|}{ Dependent Variable: Investment } \\
\hline Independent Variables & First-difference GMM & OLS & Dynamic OLS \\
\hline \multirow{2}{*}{$(I / K)_{i, t-1}$} & $1.619^{* *}$ & & $0.259 * * *$ \\
\hline & $(0.656)$ & & $(0.0792)$ \\
\hline \multirow[t]{2}{*}{$(\mathrm{CF} / \mathrm{K})_{\mathrm{i}, \mathrm{t}}$} & 0.0178 & 0.0113 & 0.000421 \\
\hline & $(0.0646)$ & $(0.0352)$ & $(0.0327)$ \\
\hline \multirow[t]{2}{*}{$(\operatorname{lnc} / \mathrm{K})_{\mathrm{i}, \mathrm{t}}$} & $0.0197^{* *}$ & $0.0149^{* * *}$ & $0.0189^{* * *}$ \\
\hline & $(0.00831)$ & $(0.00454)$ & $(0.00492)$ \\
\hline \multirow[t]{2}{*}{$(\operatorname{lnc} / K)_{i, t-1}$} & -0.0151 & -0.00111 & $-0.00657^{*}$ \\
\hline & $(0.0118)$ & $(0.00321)$ & $(0.00341)$ \\
\hline \multirow[t]{2}{*}{ Constant } & & $0.549^{* * *}$ & $0.363^{* * *}$ \\
\hline & & $(0.0471)$ & $(0.0566)$ \\
\hline No. of Observations & 464 & 1.261 & 822 \\
\hline R squared & & 0.089 & 0.467 \\
\hline No. of companies & 270 & & \\
\hline$J$ test ( $p$ value) & 0.1541 & & \\
\hline Autocorrelation Test ( $p$ value) & 0.0658 & & \\
\hline
\end{tabular}

Note: Source - Fipecafi. ${ }^{* * *} \mathrm{p}<0.01,{ }^{* *} \mathrm{p}<0.05,{ }^{*} \mathrm{p}<0.1$. Robust errors in brackets. Instruments validated by Sargan test (H0: instruments are valid). Lack of autocorrelation between errors in first difference (H0 lack of first-order autocorrelation). K: fixed assets in t-1. I: Investment. Inc: Income. 


\section{CONCLUSION}

This study analyzed the credit constraints of Brazilian companies from 2007 to 2010 by the cash flow sensitivity approach. The results showed that there is no difference in the investment-cash flow sensitivity between listed and private companies. According to the cash flow sensitivity approach, there is no difference in credit constraints between listed and private companies. This evidence suggests that the degree of information asymmetry of listed and private companies might be the same in Brazil for the analyzed sample. Additionally, the results might have been influenced by the low turnover of Brazilian listed companies, by the performance of private equity funds in private companies, and by the high rate of the disclosure of information transparency of private companies. Ano- ther interesting result was the disappearance of the investment-cash flow sensitivity during the analyzed period. A similar result was found by Chen and Chen (2012), but for companies in the US during the banking crisis there. This evidence suggests a common dynamic of investment-cash flow sensitivity for both countries during the crisis. Based on Brown and Petersen (2009), the development of the capital market and the increase in investments in intangible assets could have explained the non-dependence on cash flow for investments in fixed assets during the analyzed period. Another possible explanation might be related to credit incentives from the government that could have reduced the dependence on cash flow for investments from 2007 to 2010.

\section{References}

Almeida, H., \& Campello, M. (2007). Financial constraints, asset tangibility and corporate investments. The Review of Financial Studies, 20(5), 1429-1460

Alti, A. (2003). How sensitive is investment to cash flow when financing is frictionless? Journal of Finance, 58, 707-722.

Arellano, M., \& Bond, S. R. (1991). Some specification tests for panel data: Monte Carlo evidence and an application to employment equations. Review of Economic Studies, 58, 277-298.

Aldrighi, D. M., \& Bisinha, R. (2010). Restrição ao crédito em Empresas com Ações Negociadas na BOVESPA. Revista Brasileira de Economia, 64(1), 25-47.

Banco Céntral do Brasil (2012). Sistema Gerenciador de Séries Temporais. Recuperado em 15 julho, 2012 de https://www3.bcb.gov.br/sgspub/ localizarseries/localizarSeries.do?method=prepararTelaLocalizarSeries

Brown, J. R., \& Petersen, B. C. (2009). Why has the investment-cash flow sensitivity declined so sharply? Rising R\&D and equity market developments. Journal of Banking and Finance, 33, 971-984.

Carpenter, R. E, \& Petersen, B. C. (2002). Capital Market Imperfections, HighTech Investment, and new equity financing. The Economic Journal, 112.

Chen, H. J., \& Chen, S. J. (2012). Investment-cash flow sensitivity can-not be a good measure of financial constraints: Evidence from the time series. Journal of Fi-nancial Economics, 103, 393-410.

Cleary, S, (1999). The relationship between firm investment and financial status. Journal of Finance, 54(2), 673-692.

Cleary, S., Povel, P., \& Raith, M. (2007). The U-shaped investmetn curve: Theory and evidence. Journal of Finaricial and Quantitative Analysis, 42, 1-40.
Fazzari, S. M., Glenn, R. H., \& Petersen, B. C. (1988). Financing constraints and corporate investment. Brookings Papers on Economic Activity, 1, 141-206.

Guaraglia, A. (2008). Internal financial constraints, external financial constraints, and investment choice: Evidence from a panel of UK firms. Journal of Banking and Finance, 32, 1795-1809.

Gilchrist, S., \& Himmelberg, C. P. (1995). Evidence on the role of cash flow for investment equations. Journal of Monetary Economics, 36, 541-572.

Hoshi, T., Kashyap, A. K., \& Scharfstein, D. (1991). Corporate structure, liquidity, and investment: Evidence from Japanese panel data. Quarterly Journal of Economics, 106, 33-60.

Kadapakkam, P., Kumar, P. C., \& Riddick, L. A. (1998). The impact of cash flows and firm size on investment: The international evidence. Journal of Banking and Finance, 22, 293-320.

Kaplan, S., \& Zingales, L. (1997). Do investment cash.flow sensitivities provide useful measures of financing constraints? Quarterly Journal of Economics, 112(1), 169-215.

Moyen, N. (2004). Investment-cash flow sensitivities: constrained versus unconstrained firms. The Journal of Finance, $\operatorname{LIX}(-5)$

Ratti, R. A., Lee, S., \& Seol, Y. (2008). Bank concentration and financial constraints on firm-level investment in Europe. Journal of Banking and Finance, 31, 2684-2694.

Terra, M. C. (2003). Credit constraints in Brazilian firms: evidence from panel data. Revista Brasileira de Economia, 57(2).

Wooldridge, J. M. (2002). Econometric analysis of cross section and panel data. Cambridge, Mass.: MIT Press. 